\title{
PERSEPSI PEMILIK PROYEK DALAM LINGKUNGAN LPSE TERHADAP PENILAIAN KINERJA KONTRAKTOR
}

\author{
Nurhidayati*1 $^{1}$, As'ad Munawir ${ }^{2}$ dan Eko Andi Suryo ${ }^{3}$ \\ ${ }^{1}$ Mahasiswa / Magister / Teknik Sipil / Universitas Brawijaya \\ ${ }^{2,3}$ Dosen / Teknik Sipil / Universitas Brawijaya \\ Korespondensi : nurhidayati.ahmad25@gmail.com
}

\begin{abstract}
Good contractor performance can provide satisfaction for owners. The research is to identify factors influencing owners perception in assessing contractor performance in UB. Method of analysis using Importance Performance Analysis and Customer Satisfaction Index. The results of the analysis show satisfaction of $75.22 \%$ and $71.69 \%$ means that the owner is satisfied with the performance of their contractor. Attributes that are prioritized for improvement/improvement include: completion of work in accordance with the contract; the filing of MC-O is done before the work begins; ability of human resources in handling material delays/scarcity, workers crisis, design change, environmental security, etc .; as well as the speed \& willingness to repair the damaged buildings around the project site.
\end{abstract}

Keywords: CSI, IPA Analysis, Owner Perception

\section{PENDAHULUAN}

Dewasa ini kebutuhan masyarakat di berbagai belahan dunia tak terkecuali Indonesia telah mengalami peningkatan cukup signifikan di berbagai bidang kehidupan termasuk di antaranya adalah di bidang pembangunan. Tidak dapat dipungkiri bahwa pembangunan merupakan prioritas sebagian besar masyarakat dan pemerintah untuk bersaing di era globalisasi seperti sekarang.

Dalam dunia pendidikan khususnya pendidikan tinggi pembangunan infrastruktur sebagai penunjang perkuliahan juga mengalami perkembangan yang signifikan. Keinginan untuk menyelenggarakan pendidikan yang berkualitas dan bertaraf internasional telah membuat berbagai lembaga pendidikan meningkatkan daya tampung dan kualitas bangunan untuk memberikan rasa nyaman dan aman kepada seluruh civitas akademi.

Seperti halnya Universitas Brawijaya, sebagai kampus yang ternama di Kota Malang Universitas Brawijaya dari tahun ketahun terus meningkatkan kualitas infrastruktur penunjang pendidikan. Seperti terlihat dalam website Layanan Pengadaan Secara Elektronik (LPSE) Universitas Brawijaya untuk tahun 2011 sampai dengan tahun 2016 telah melaksanakan pelelangan pekerjaan konstruksi sebanyak 162 pelelangan (sumber: LPSE Universitas Brawijaya)

Sebagai perguruan tinggi yang menerapkan LPSE dengan kurun waktu yang lama serta dalam penyelengaan pembangunan yang kontinyu setiap tahun Univeritas Brawijaya sering digunakan sebagai rujukan dan tolak ukur oleh berbagai instansi pendidikan lain dalam menyelenggarakan pembangunan di lingkungan mereka. Hal ini tidak lain karena pengendalian kualitas produk yang dihasilkan di lingkungan Universitas Brawijaya sangat baik dan memiliki mutu yang bagus.

Dalam pengendalian kualitas di tahap pelaksanaan, Universitas Brawijaya melibatkan pihak-pihak yang memiliki kompetensi di bidang konstruksi dengan membentuk tim teknis. Fungsi dari tim teknis adalah sebagai wakil pemilik proyek dalam mengawasi, dan mengendalikan kualitas pada saat pelaksanaan konstruksi bersama-sama dengan konsultan pengawas agar pekerjaan tetap sesuai dengan spesifikasi yang telah ditentukan dalam dokumen kontrak.

Faktor-faktor dalam penelitian ini mengacu pada penelitian yang telah 
dikembangkan Idrus dan Sodagi (2011) dalam Riqhi Radian Kasani (2013) [1] tentang membuat kerangka untuk evaluasi kinerja kualitas dari kontraktor di Nigeria, yang mendefinisikan kepuasan konstruksi pada level proyek terbagi menjadi 2 dimensi, yaitu dimensi produk dan dimensi pelayanan (service). Sasaran penelitian sebagai berikut:

1. Mengidentifikasi faktor-faktor yang menjadi dasar penilaian persepsi pemilik proyek dalam menilai kinerja kontraktor pada kriteria produk dan servis (layanan),

2. Melaksanakan pengukuran kinerja

kontraktor di lingkungan LPSE,

3. Mengidentifikasi faktor-faktor lain yang

mempengaruhi kinerja kontraktor,

\section{TINJAUAN PUSTAKA}

\subsection{Persepsi Pemilik Proyek}

Persepsi pada hakikatnya merupakan proses pengenalan maupun proses pemberian arti terhadap lingkungan oleh individu [2]. Dengan adanya persepsi maka akan terbentuk sikap, yaitu kecenderungan yang stabil untuk berlaku atau bertindak secara tertentu di dalam situasi yang tertentu pula.

Pemilik proyek atau pemberi tugas adalah orang atau badan yang memiliki proyek dan memberikan pekerjaan kepada pihak penyedia jasa dan yang membayar biaya pekerjaan tersebut [3].

Sesuai dengan Perpres RI nomor 54 Tahun 2010 tentang pengadaan barang/jasa pemerintah [4] pemilik proyek selanjutnya disebut sebagai pengguna anggaran. Dalam menjalan fungsinya PA salah satunya menunjuk tim teknis dan panitia penerima hasil pekerjaan untuk mengontrol serta memeriksa hasil kerja kontraktor.

\subsection{Kinerja Kontraktor}

Kinerja atau performance sering diartikan sebagai hasil kerja atau prestasi kerja. Kinerja mempunyai makna yang lebih luas, bukan hanya menyatakan hasil kerja, tetapi juga bagaimana proses kerja berlangsung. Hal ini mempunyai hubungan kuat dengan tujuan strategis organisasi, kepuasan konsumen dan memberikan kontribusi ekonomi (Wibowo, 2007, dalam (Nyoman Koriawan, 2011)[5].

Kontraktor adalah orang atau badan hukum yang menerima pekerjaan dan menyelenggarakan pelaksanaan pekerjaan sesuai dengan biaya yang telah ditetapkan berdasarkan gambar rencana, peraturan, dan syarat-syarat yang telah ditetapkan [3].

Kinerja kontraktor dikategorikan menjadi 2,yaitu: kategori produk dan servis (layanan). Kategori produk meliputi: bahan dan kualitas, estetika, keamanan, kelengkapan. Kategori servis (layanan) meliputi: aktualitas, konsistensi, responsive dan keamanan, kebersihan

\subsection{Analisis Statistik}

Pengolahan data dianalisis dengan menggunakan bantuan program Statistical Program for Social Science (SPSS) yang merupakan program pengolah data statistik. Tahapan pengolahan data adalah sebagai berikut :

Uji validitas dan reliabilitas digunakan untuk mengetahui konsistensi atau stabilnya suatu jawaban. Instrumen valid berarti alat ukur yang digunakan dapat mengukur apa yang seharusnya diukur, dan dikatakan reliabel jika memberikan hasil tetap apabila diujikan berkali-kali. Koefisien korelasi dilakukan dengan persamaan yang ditemukan oleh Karl Pearson [6]:

$$
\rho=\frac{n \sum X Y_{i}-\sum X \sum X_{i}}{\sqrt{\sum X^{2}-\left(\sum X^{2}\right) \cdot \sqrt{n \sum X_{i}-\left(\sum X_{i}^{2}\right)}}}
$$

dengan :

$$
\begin{array}{ll}
\rho & =\text { koefisien korelasi } \\
\mathrm{X} & =\text { skor item } \mathrm{X} \\
\mathrm{X}_{\mathrm{i}} & =\text { skor total item } \mathrm{X} \\
\mathrm{n} & =\text { banyaknya responden }
\end{array}
$$

Uji reliabilitas digunakan untuk mengetahui konsistensi alat ukur. Uji dilakukan dengan melihat nilai alfa Cronbach. Persamaan yang ditemukan oleh Lee Cronbach digunakan untuk mencari nilai ini adalah :

$$
\alpha=\left[\frac{k}{k-1}\right]\left[1-\frac{\sum a_{b^{2}}}{a_{n^{2}}}\right]
$$

dengan :

$\alpha=$ reliabilitas instrumen (alfa Cronbach)

$\mathrm{K}$ = banyaknya item pertanyaan

$\sum a_{b^{2}}=$ jumlah varian butir

$a_{1^{2}}=$ varian total

\subsection{Analisis Importance Performance Analysis (IPA) \\ Importance Performance Analysis (IPA)} secara konsep merupakan suatu model multiatribut. Tehnik ini mengidentifikasi kekuatan dan kelemahan penawaran pasar dengan 
menggunakan dua kriteria yaitu kepentingan relatif atribut dan kepuasan konsumen. Penerapan teknik IPA dimulai dengan identifikasi atribut-atribut yang relevan terhadap situasi pilihan yang diamati. Daftar atribut-atribut dapat dikembangkan dengan mengacu kepada literatur-literatur, melakukan interview, dan menggunakan penilaian manajerial [7].

Adapun langkah-langkah analisis IPA sebagai berikut:

1. menghitung rata-rata penilaian kepentingan dan kinerja setiap produk layanan serta menghitung tingkat kesesuaian dengan rumus:

$\overline{X_{l}}=\frac{\sum_{i=1}^{k} X i}{n}$;

$\overline{Y_{l}}=\frac{\sum_{i=1}^{k} Y_{i}}{n}$

$\mathrm{Tki}=\frac{\Sigma_{\mathrm{xi}}}{\mathrm{z}_{\mathrm{yi}}}$

dengan :

$\overline{X \imath}=$ Bobot rata-rata tingkat kepuasan ke-i 2

$\bar{Y} \quad=$ Bobot rata-rata tingkat kepentingan ke-i

$\mathrm{n} \quad=$ Jumlah responden

Tki $=$ Tingkat kesesuaian

$\Sigma x i=$ Skor penilaian kinerja

$\Sigma y i=$ Skor penilaian kepentingan

Tingkat kesesuaian inilah yang akan menentukan urutan prioritas peningkatan faktor-faktor yang dapat mempengaruhi kualitas pelayanan. Kriteria pengujian:

- Apabila Tki < $100 \%$, berarti pelayanan belum memuaskan,

- Apabila Tki $=100 \%$, berarti pelayanan telah memuaskan,

- Apabila Tki > $100 \%$, berarti pelayanan sangat memuaskan,

2. menghitung rata-rata tingkat kepentingan dan kepuasan untuk keseluruhan produk layanan dengan rumus:

$$
\begin{gathered}
\overline{\overline{X_{l}}}=\frac{\sum_{i=1}^{k} \overline{X_{l}}}{n} \\
\overline{\overline{Y_{l}}}=\frac{\sum_{i=1}^{k} \overline{Y_{l}}}{n}
\end{gathered}
$$

dengan :

$\overline{\overline{X_{l}}} \quad=$ Nilai rata-rata kepuasan atribut

$\overline{\overline{Y_{l}}} \quad=$ Nilai rata-rata kepentingan atribut

$\mathrm{n} \quad=$ Jumlah produk layanan

3. pembuatan peta posisi IPA

4. pembuatan diagram kartesius $I P A$

5. memplotkan hasil analisa masing-masing variabel ke dalam diagram kartesisus yang terbagi menjadi empat kuadran (kuadran A, kuadran B, kuadran C, dan kuadran D)

\subsection{Analisis Customer Satisfaction Index}

Selanjutnya dilakukan analisis CSI (Customer Satisfaction Index) digunakan untuk mengetahui tingkat kepuasan pemilik proyek secara menyeluruh dengan melihat tingkat kepentingan dari produk-produk layanan. Untuk mengetahui besarnya CSI, maka dapat dilakukan langkah-langkah sebagai berikut:

1. Menentukan Mean Importance Score (MIS). Nilai ini berasal dari rata-rata kepentingan tiap konsumen.

2. Membuat Weight Factors (WF) dengan rumus :

$$
\mathrm{WF}=\frac{\text { MIS }}{\text { Total MIS }} \times 100 \%
$$

3. Membuat Weight Score (WS) dengan rumus: $\mathrm{WS}=\mathrm{WF} \times \mathrm{MSS}$

4. Menghitung weighted average total (WAT) dengan rumus :

$$
\mathrm{WAT}=\mathrm{WS} 1+\mathrm{WS} 22+\ldots \ldots .+\mathrm{WS} 27 \text { (10) }
$$

5. Menghitung customer satisfaction index (CSI), skala maksimal yang digunakan (skala penilaian 5) [8] dengan rumus :

$$
\mathrm{CSI}=\frac{W A T}{H S} \times 100 \%
$$

Dalam penelitian ini nilai

$$
\mathrm{RS}=(100-0) / 5 \times 100 \%=20 \% .
$$

Berdasarkan hasil perhitungan rentang skala maka kriteria kepuasannya adalah sebagai berikut:

$$
\begin{array}{ll}
0 \%<\mathrm{CSI} \leq 20 \% & =\text { sangat tidak puas } \\
20 \%<\mathrm{CSI} \leq 40 \% & =\text { tidak puas } \\
40 \%<\mathrm{CSI} \leq 60 \% & =\text { cukup puas } \\
60 \%<\mathrm{CSI} \leq 80 \% & =\text { puas } \\
80 \%<\mathrm{CSI} \leq 100 \% & =\text { sangat puas }
\end{array}
$$

\section{METODE PENELITIAN}

\subsection{Variabel Penelitian}

Variabel pada penelitian ini dikembangkan dari penelitian terdahulu oleh Riqhi Radian Kasani (2013)[1] dan wawancara. 


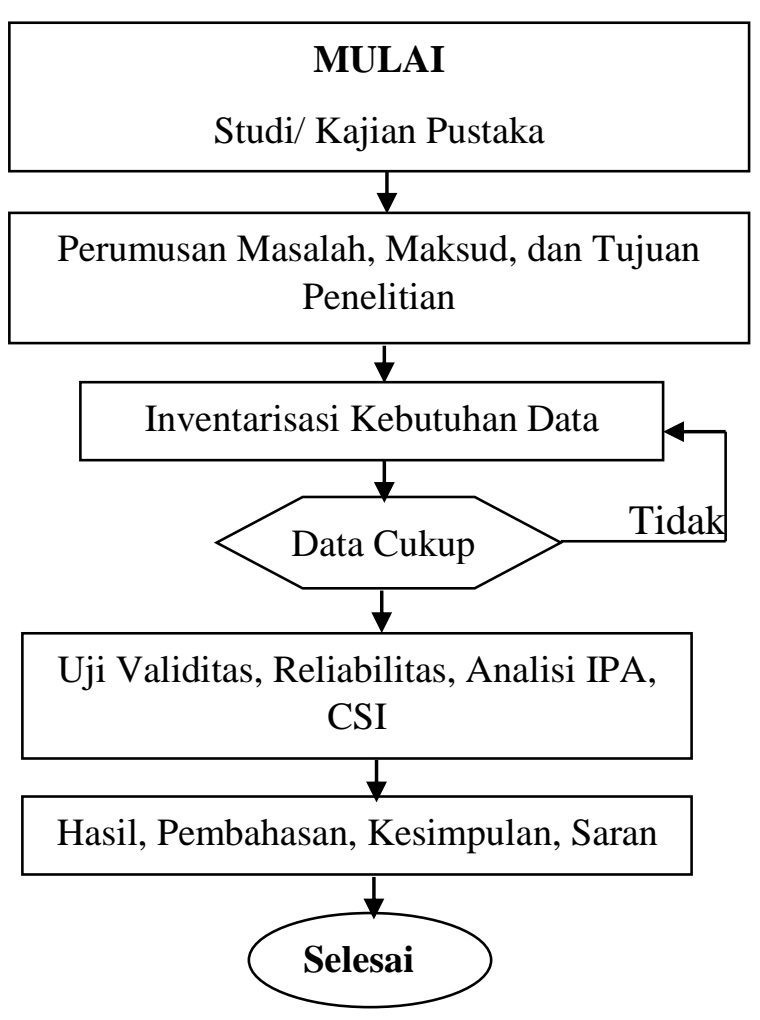

Gambar 1. Diagram alir penelitian terdiri:

Variabel bebas pada penelitian ini yaitu

Variabel penilaian tim teknis

\section{Faktor produk}

Bahan \& kualitas :

- Bekisting tidak menggunakan kayu randu (X1.1),

- Besi tulangan berstandar SNI serta tidak berkarat (X1.2),

- PC tidak menggumpal (kadaluarsa) (X1.3), pc menggunakan 1 (satu) jenis merk selama pekerjaan (X1.4),

- Komposisi beton sesuai dengan spesifikasi teknis (X1.5),

- Hasil uji beton memenuhi persyaratan teknis (X1.6)

Estetika :

- Kondisi tampilan bangunan sesuai dengan perencanaan (X1.7),

- Tata ruang bangunan sesuai perencanaan dan layak untuk kegiatana KBM (X1.8).

Keamanan :

- Bangunan terbebas dari kerusakan struktur (X1.9),

- Bangunan terbebas dari kerusakan lantai dan dinding (X1.10),
- Instalasi listrik terpasang aman dan tidak membahayakan penghuni (X1.11),

- Bangunan terbebas dari kerusakan sanitasi dan plumbing (X1.12),

- Bangunan terbebas dari bahaya akibat petir (X1.13).

Kelengkapan :

- Volume terpasang sesuai dengan kontrak (X1.14),

- Keseluruhan pekerjaan telah dilaksanakan/ dikerjakan (X1.15).

\section{Faktor servis}

Aktualitas :

- Penyelesaian pekerjaan sesuai dengan kontrak (X2.1),

- Tidak terjadi keterlambatan $>20 \%$ pada periode I dan keterlambatan $>10 \%$ pada periode II (X2.2)

Konsistensi :

- Pengajuan MC-0 dilakukan sebelum pekerjaan dimulai (X2.3),

- Pengawasan \& pengendalian mutu dilaksanakan secara kontinyu (X2.4),

- Minimnya pekerjaan rework karena kesalahan pelaksanaan (X2.5),

- Laporan kemajuan didasarkan atas prosentase pekerjaan terpasang (X2.6).

Responsive \& keamanan :

- Kemampuan SDM dalam menangani keterlambatan/kelangkaan material, krisis pekerja, perubahan desain, keamanan lingkungan, dll (X2.7),

- Kecepatan \& kemauan melakukan perbaikan kerusakan bangunan disekitar lokasi proyek (X2.8),

- Adanya security proyek (X2.9),

- Peralatan proyek tidak membahayakan lingkungan sekitar (X2.10),

- Seluruh tenaga kerja dilindungi oleh asuransi (ASTEK) (X2.11)

Kebersihan :

- jalan disekitar lokasi terbebas dari sisa material (X2.12),

- Pembuangan limbah kontruksi diluar lokasi pekerjaan (X2.13)

Variabel penilaian panitia penerima

Kesesuaian, fungsi, dan kelengkapan :

- Kesesuaian produk terpasang dengan kontrak (X1),

- Volume terpasang sesuai dengan kontrak (X2),

- Item terpasang berfungsi dengan baik (X3), 
- Keseluruhan pekerjaan telah dilaksanakan (X4).

Keamanan :

- Bangunan terbebas dari kerusakan lantai \& dinding (X5),

- Instalasi listrik terpasang aman \& tidak membahayakan penghuni (X6),

- Bangunan terbebas dari kerusakan sanitasi \& plumbing (X7).

Estetika :

- Tampilan akhir bangunan sesuai perencanaan (X8),

- Bangunan diterima dalam keadaan rapi , bersih, dan tidak terdapat sisa material (X9).

\subsection{Populasi dan Sampel}

Populasi penelitian ini adalah kontraktor yang telah memenangkan pelelangan umum dan melakukan kontrak kerja dengan Universitas Brawijaya tahun anggaran 2016 dengan nilai kontrak minimal 4,5 milyar rupiah serta dalam uraian pekerjaannya terdapat pekerjaan struktur maupun finishing.

Dari 11 proyek pembangunan yang dikerjakan, hanya 6 proyek pembangunan yang memenuhi kriteria tersebut, yaitu pembangunan gedung perkuliahan teknik pengairan fakultas teknik, pembangunan gedung baru 12 lantai tahap 2 fakultas ilmu administrasi, pembangunan gedung $\mathrm{B}$ fakultas kedokteran hewan, pembangunan gedung kuliah bersama fakultas kedokteran, pembangunan lab. riset (GLP dan GMP) kampus 2 dieng, dan pembangunan gedung kuliah MIPA center tahap 4 .

Responden pada penelitian ini dibagi menjadi 2, yaitu: (1) tim teknis, merupakan tim ahli bangunan dengan kualifikasi dan latar belakang pendidikan teknik S1, S2, dan S3 dengan pengalaman mengelola proyek lebih dari 6 tahun, (2) tim penerima hasil pekerjaan, merupakan tim dengan kualifikasi dan latar belakang pendidikan teknik dan nonteknik SMA, S1, S2, dan S3 dengan pengalaman mengelola proyek pemerintah lebih dari 6 tahun.

\section{HASIL DAN PEMBAHASAN \\ 4.1 Analisis Statistik}

\subsubsection{Uji Validitas dan Reliabilitas}

Kriteria pengujian validitas jika $\rho>\mathrm{r}$ tabel maka indikator dinyatakan valid. Dengan menggunakan tabel distribusi (tabel $r$ ) untuk $\alpha$ $=0,05$ dan jumlah responden sebanyak 40 responden terdiri dari 20 responden tim teknis dan 20 responden panitia penerima, sehingga didapat $\mathrm{r}$ tabel $=0,44$. Setelah dilakukan perhitungan dengan teknik Pearson Product Moment dengan persamaan (1) maka seluruh variabel produk dan servis dinyatakan valid.

Selanjutnya uji reliabilitas dilakukan dengan melihat nilai alfa Cronbach dengan menggunakan persamaan (2). Variabel produk dan servis pada tingkat kepentingan dan kepuasan tim teknis adalah 0.83, 0.89 dan 0.86, 0.83 dengan reliabilitas baik (Sekaran, 2006)[8]. Sedangkan variabel produk pada tingkat kepentingan dan kepuasan panitia penerima adalah 0.73 dan 0.71 dengan reliabilitas diterima (Sekaran, 2006)[8].

\subsubsection{Analisis IPA}

Hasil perhitungan tingkat kesesuaian variabel dan tingkat kesesuaian total pada masing-masing proyek dapat ditunjukkan pada tabel berikut:

Tabel 1. Penilaian tingkat kesesuaian total oleh tim teknis

\begin{tabular}{|c|c|c|}
\hline No & Uraian & $\begin{array}{l}\text { Tki Total } \\
(\%)\end{array}$ \\
\hline 1 & $\begin{array}{lr}\text { Pembangunan } & \text { gedung } \\
\text { perkuliahan } & \text { teknik } \\
\text { pengairan fakultas teknik }\end{array}$ & 79.98 \\
\hline 2 & $\begin{array}{l}\text { Pembangunan gedung baru } \\
12 \text { lantai tahap } 2 \text { fakultas } \\
\text { ilmu administrasi }\end{array}$ & 108.67 \\
\hline 3 & $\begin{array}{l}\text { Pembangunan gedung B } \\
\text { fakultas kedokteran hewan }\end{array}$ & 93.60 \\
\hline 4 & $\begin{array}{ll}\text { Pembangunan } & \text { gedung } \\
\text { kuliah bersama fakultas } \\
\text { kedokteran }\end{array}$ & 118.48 \\
\hline 5 & $\begin{array}{l}\text { Pembangunan lab. riset } \\
\text { (GLP dan GMP) kampus } 2 \\
\text { dieng }\end{array}$ & 106.81 \\
\hline 6 & $\begin{array}{l}\text { Pembangunan gedung } \\
\text { kuliah MIPA center tahap } 4\end{array}$ & 112.41 \\
\hline
\end{tabular}

Berdasarkan Tabel 1 menunjukkan bahwa tingkat pelayanan kontraktor secara keseluruhan ada yang belum memuaskan, yaitu pada pelaksanaan proyek pembangunan gedung perkuliahan teknik pengairan fakultas teknik dan pembangunan gedung $\mathrm{B}$ fakultas kedokteran hewan dengan tingkat kesesuaian total $79,98 \%$ dan $93,60 \%$. 
Tabel 2. Penilaian tingkat kesesuaian masingmasing variabel \& kesesuaian total oleh panitia penerima hasil pekerjaan Pekerjaan teknik pengairan

\begin{tabular}{ccccc}
\hline No & Variabel & Xi & Yi & Tki (\%) \\
\hline 1 & X1 & 11 & 11 & 100 \\
2 & X2 & 9 & 13 & 69.23 \\
3 & X3 & 9 & 11 & 81.82 \\
4 & X4 & 9 & 11 & 81.82 \\
5 & X5 & 11 & 10 & 110 \\
6 & X6 & 11 & 11 & 100 \\
7 & X7 & 8 & 11 & 72.73 \\
8 & X8 & 11 & 10 & 110 \\
9 & X9 & 8 & 8 & 100 \\
\hline \multicolumn{2}{r}{ Rata-rata } & 87 & 96 & 90.63 \\
\hline \multicolumn{7}{c}{}
\end{tabular}

Berdasarkan Tabel 2 menunjukkan bahwa tingkat pelayanan kontraktor pada variabel X2, X3, X4, X7 belum memuaskan. Variabel $\mathrm{X} 1, \mathrm{X6}$, dan X9 memuaskan. Dan variabel X5 dan X8 sangat memuaskan.

\subsubsection{Matrix Performance Important Analysis (Analisis Keempat Kuadran)}

Tabel 3. Rata-rata tingkat kepuasan dan kepentingan tiap variabel

\begin{tabular}{|c|c|c|c|}
\hline No & Uraian & $\mathrm{Xi}$ & $\mathrm{Yi}$ \\
\hline 1 & $\begin{array}{lr}\text { Pembangunan } & \text { gedung } \\
\text { perkuliahan } & \text { teknik } \\
\text { pengairan fakultas teknik }\end{array}$ & 3.31 & 4.19 \\
\hline 2 & $\begin{array}{l}\text { Pembangunan gedung } \\
\text { baru } 12 \text { lantai tahap } 2 \\
\text { fakultas ilmu administra- } \\
\text { si }\end{array}$ & 4.03 & 3.71 \\
\hline 3 & $\begin{array}{l}\text { Pembangunan gedung B } \\
\text { fakultas kedokteran he- } \\
\text { wan }\end{array}$ & 3.31 & 3.54 \\
\hline 4 & $\begin{array}{l}\text { Pembangunan gedung } \\
\text { kuliah bersama fakultas } \\
\text { kedokteran }\end{array}$ & 4.14 & 3.75 \\
\hline No & Uraian & $\mathrm{Xi}$ & $\mathrm{Yi}$ \\
\hline 5 & $\begin{array}{l}\text { Pembangunan lab. riset } \\
\text { (GLP dan GMP) kampus } \\
2 \text { dieng }\end{array}$ & 3.92 & 3.67 \\
\hline 6 & 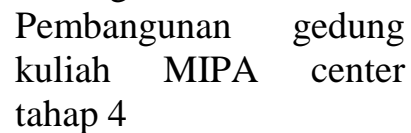 & 3.77 & 3.36 \\
\hline
\end{tabular}

Berdasarkan perhitungan telah diperoleh nilai rata-rata tingkat kepuasan dan tingkat kepentingan dari masing-masing variabel pengukuran kinerja kontraktor. Rata-rata tingkat kepuasandan tingkat kepentingan tersebut dapat dilihat pada Tabel 3 .

Selanjutnya dari perhitungan tabel di atas akan digambarkan posisi tingkat kepuasan dan tingkat kepentingan dari penilaian persepsi pemilik proyek dengan memplotkan nilai mean masing-masing variabel pada diagram kartesius, dimana mean kepuasan pada sumbu (x) dan mean kepentingan pada sumbu (y) dengan titik perpotongan sumbu $(\mathrm{x}, \mathrm{y})$ yang didapat dari perhitungan rata-rata keseluruhan nilai mean variabel yaitu $(\mathrm{x}=3.31 ; \mathrm{y}=4.19)$. Diagram kartesius persepsi pemilik proyek dalam menilai kinerja kontraktor dapat dilihat pada Gambar 1.

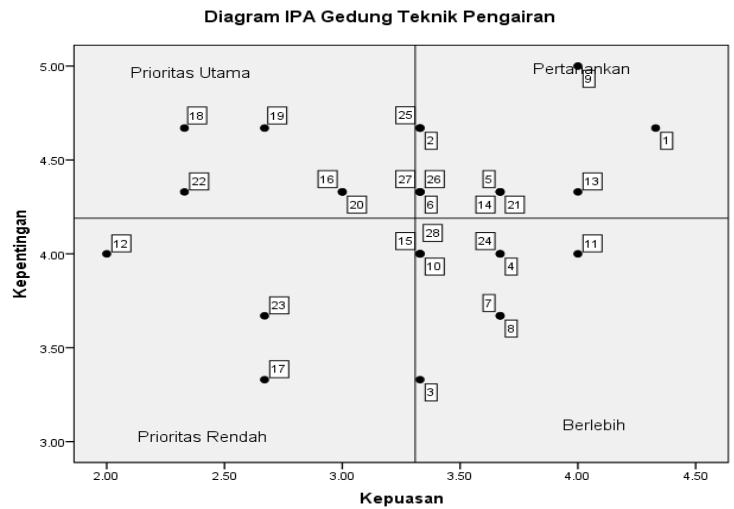

Gambar 1. Grafik IPA pembangunan gedung teknik pengairan fakultas teknik

Dari Gambar 1 menunjukkan bahwa faktor-faktor yang menjadi prioritas utama untuk ditingkat kinerjanya meliputi:

- Penyelesaian pekerjaan sesuai dengan kontrak (2.1)

- Pengajuan MC-0 dilakukan sebelum pekerjaan dimulai (2.3)

- Pengawasan \& pengendalian mutu dilakukan secara kontinyu (2.4)

- Minimnya pekerjaan rework karena kesalahan pelaksanaan (2.5)

- Kemampuan SDM dalam menangani keterlambatan/kelangkaan material, krisis pekerja, perubahan desain, keamanan lingkungan, dll (2.7) 


\subsubsection{Customer Satisfaction Index (CSI)}

Berdasarkan penilaian yang dilakukan oleh tim teknis dan panitia penerima hasil pekerjaan maka dapat diketahui bahwa Index Performance kinerja kontraktor adalah sebesar $75.22 \%$ dan $71.69 \%$, nilai tersebut berada pada rentang nilai $C S I$ yaitu antara $(60 \%<$ CSI $\leq$ $80 \%$ ) yang berarti bahwa pelanggan merasa puas atas kinerja kontraktor.

Tabel 4. Customer Satisfaction Index (CSI) Tim Teknis terhadap kinerja kontraktor

\begin{tabular}{|c|c|c|c|c|}
\hline Variabel & $M I S$ & $W F$ & $M S S$ & $W S$ \\
\hline $\mathrm{X} 1.1$ & 3.95 & 0.04 & 4.45 & 0.17 \\
\hline $\mathrm{X} 1.2$ & 4.25 & 0.04 & 3.75 & 0.15 \\
\hline X1.3 & 3.05 & 0.03 & 3.8 & 0.11 \\
\hline X1.4 & 3.2 & 0.03 & 3.95 & 0.12 \\
\hline X1.5 & 3.85 & 0.04 & 3.95 & 0.15 \\
\hline X1.6 & 4 & 0.04 & 3.95 & 0.15 \\
\hline X1.7 & 3.5 & 0.03 & 3.65 & 0.12 \\
\hline $\mathrm{X} 1.8$ & 3.25 & 0.03 & 4.1 & 0.13 \\
\hline X1.9 & 4.55 & 0.04 & 4.15 & 0.18 \\
\hline X1.10 & 3.75 & 0.04 & 3.65 & 0.13 \\
\hline X1.11 & 3.6 & 0.03 & 3.5 & 0.12 \\
\hline $\mathrm{X} 1.12$ & 3.7 & 0.04 & 3.2 & 0.11 \\
\hline X1.13 & 3.85 & 0.04 & 3.55 & 0.13 \\
\hline X1.14 & 3.65 & 0.04 & 3.8 & 0.13 \\
\hline X1.15 & 3.8 & 0.04 & 3.9 & 0.14 \\
\hline $\mathrm{X} 2.1$ & 3.8 & 0.04 & 3.7 & 0.14 \\
\hline $\mathrm{X} 2.2$ & 3.35 & 0.03 & 3.5 & 0.11 \\
\hline $\mathrm{X} 2.3$ & 3.9 & 0.04 & 3.45 & 0.13 \\
\hline $\mathrm{X} 2.4$ & 3.85 & 0.04 & 3.7 & 0.14 \\
\hline $\mathrm{X} 2.5$ & 3.35 & 0.03 & 3.5 & 0.11 \\
\hline $\mathrm{X} 2.6$ & 3.35 & 0.03 & 4.05 & 0.13 \\
\hline $\mathrm{X} 2.7$ & 3.85 & 0.04 & 3.5 & 0.13 \\
\hline $\mathrm{X} 2.8$ & 3.65 & 0.04 & 3.45 & 0.12 \\
\hline X2.9 & 3.55 & 0.03 & 3.9 & 0.13 \\
\hline $\mathrm{X} 2.10$ & 3.85 & 0.04 & 3.8 & 0.14 \\
\hline $\mathrm{X} 2.11$ & 3.6 & 0.03 & 4.05 & 0.14 \\
\hline $\mathrm{X} 2.12$ & 3.9 & 0.04 & 3.55 & 0.13 \\
\hline $\mathrm{X} 2.13$ & 3.55 & 0.03 & 3.75 & 0.13 \\
\hline Jumlah & 103.5 & & & \\
\hline \multicolumn{4}{|c|}{ Weighted Total $=$ Eweighting Score } & 3.76 \\
\hline \multicolumn{4}{|c|}{$\begin{array}{l}\text { Satisfaction Index }=\text { Weighted To- } \\
\text { tal/Scale (5) } x\end{array}$} & 75.22 \\
\hline
\end{tabular}

4.2. Faktor Lain Yang Mempengaruhi Kinerja Kontraktor

Faktor eksternal terdiri dari:

1. Produk perencanaan konsultan

Perencanaan harus memperhatikan detail gambar, kesesuaian antara gambar dengan
$\mathrm{RAB}$, perencanaan yang tidak berubah-ubah, kesesuaian harga.

2. Peran konsultan pengawas

3. Durasi kontrak

4. Waktu anggaran

Waktu anggaran merupakan periode waktu yang ditetapkan pemerintah dalam memberikan batasan-batasan kegiatan. Biasanya waktu anggaran ditetapkan selama 1 tahun per periode anggaran. Pelaksanaan konstruksi di Indonesia dibatasi oleh waktu anggaran ini, hal inilah secara tidak langsung mempengaruhi kinerja kontraktor dan mutu suatu bangunan. Suatu bangunan dipaksa selesai mengikuti berakhirnya masa anggaran. Jika hal ini terus dilakukan maka hasil pekerjaan konstruksi di Indonesia tidak akan bisa mencapai mutu yang baik.

Faktor internal yang mempengaruhi kinerja kontraktor terdiri dari:

1. Pengalaman kerja

Pengalaman kerja kontraktor akan mempengaruhi performance mereka di lapangan, penggunaan metode kerja, pengaturan pekerja, pengkoordinasian material yang tentunya akan memberikan hasil akhir berupa kualitas bangunan yang baik.

2. Management perusahaan

3. Harga penawaran

Dengan adanya sistem e-procurment membuat persaingan pada industri konstruksi semakin meningkat hal ini berdampak pada harga penawaran yang diajukan oleh kontraktor terkadang dibawah kewajaran.

Tabel 5. Customer Satisfaction Index (CSI) panitia penerima hasil pekerjaan terhadap kinerja kontraktor

\begin{tabular}{|c|c|c|c|c|}
\hline Variabel & $M I S$ & $W F$ & $M S S$ & $W S$ \\
\hline $\mathrm{X} 1$ & 4.1 & 0.12 & 3.75 & 0.44 \\
\hline $\mathrm{X} 2$ & 4.3 & 0.12 & 3.7 & 0.46 \\
\hline X3 & 4.45 & 0.13 & 3.85 & 0.50 \\
\hline $\mathrm{X} 4$ & 3.7 & 0.11 & 3.55 & 0.38 \\
\hline X5 & 3.9 & 0.11 & 3.6 & 0.41 \\
\hline X6 & 3.6 & 0.10 & 3.45 & 0.36 \\
\hline $\mathrm{X} 7$ & 3.8 & 0.11 & 3.15 & 0.35 \\
\hline $\mathrm{X} 8$ & 3.5 & 0.10 & 3.85 & 0.39 \\
\hline X9 & 4.25 & 0.09 & 3.25 & 0.31 \\
\hline Total & 34.6 & & & \\
\hline \multicolumn{4}{|c|}{ Weighted Total $=\Sigma$ weighting Score } & 3.58 \\
\hline \multicolumn{5}{|c|}{$\begin{array}{l}\text { Satisfaction Index }=\text { Weighted To- } 71.69 \\
\text { tal/Scale (5) } x\end{array}$} \\
\hline
\end{tabular}


Hal itu dilakukan agar mereka bisa memenangkan pelelangan. Tentunya hal ini tidak bisa dibiarkan terus menerus, pokja pengadaan harus memberikan sistem evaluasi pengadaan yang tidak hanya mengedepankan sistem penilaian harga terendah yang bisa memenangkan pelelangan, akan tetapi dengan evaluasi sistem nilai akan memberikan keuntungan bagi kedua belah pihak, yaitu kontraktor dan pemilik proyek.

4. Modal

Modal perusahaan sangat berpengaruh terhadap kinerja kontraktor. hal ini dikarenakan selama masa konstruksi kontraktor tidak hanya mengandalkan pencairan termin dari kontrak.

\section{KESIMPULAN DAN SARAN}

\subsection{Kesimpulan}

1. Faktor-faktor yang menjadi dasar penilaian pemilik proyek dalam kriteria produk dan servis (layanan) terhadap kinerja kontraktor terdiri dari: kriteria produk (tim teknis): bahan dan kualitas, estetika, keamanan bangunan, dan kelengkapan hasil pekerjaan; kriteria servis (tim teknis) : aktualitas, konsistensi, responsive dan keamanan, kebersihan; dan kriteria produk (panitia penerima hasil pekerjaan) : kesesuaian, volume, fungsi, keamanan, estetika, dan kebersihan.

2. Secara keseluruhan pemilik proyek telah merasa puas terhadap kinerja kontraktor di lingkungan Universitas Brawijaya, hal ini bisa terlihat dari hasil perhitungan IP (Index Performance) tim teknis dan panitia penerima sebesar $75.22 \%$ dan $71.69 \%$. Ada beberapa atribut yang harus mendapat prioritas perbaikan/peningkatan, diantaranya adalah: penyelesaian pekerjaan sesuai dengan kontrak; pengajuan MC-0 dilakukan sebelum pekerjaan dimulai; kemampuan SDM dalam menangani keterlambatan/kelangkaan material, krisis pekerja, perubahan desain, keamanan lingkungan, dll; serta kecepatan \& kemauan melakukan perbaikan kerusakan bangunan disekitar lokasi proyek;

3. Selain faktor produk dan servis (layanan) terdapat faktor lain yang bisa mempengaruhi kinerja kontraktor yaitu terdiri dari faktor eksternal dan faktor internal. Faktor eksternal terdiri dari: produk perencanaan konsultan (detail gambar, kesesuaian antara gambar dengan RAB, perencanaan yang tidak berubah- ubah, kesesuaian harga), banyak sedikitnya addendum, peran konsultan pengawas, durasi kontrak, dan waktu anggaran.

Faktor internal yang mempengaruhi kinerja kontraktor terdiri dari: pengalaman kerja, management perusahaan, SDM perusahaan, harga penawaran, dan modal.

\subsection{Saran}

\section{Bagi kontraktor}

Diharapkan kontraktor dapat melakukan peningkatan kinerja pada atribut-atribut yang dinilai pemilik proyek penting dan yang akan memberikan kepuasan kepada pengguna gedung.

\section{Bagi pemilik proyek}

Diharapkan pemilik proyek konsisten dan memaksimalkan produk perencanaan supaya tidak terjadi perubahan-perubahan diluar perencanaan yang bisa menghambat waktu pelaksanaan.

3. Bagi peneliti selanjutnya

Disarankan untuk melakukan penelitian dengan ruang lingkup lebih luas misalnya kredibilitas konsultan perencana, serta menggunakan metode AHP

\section{DAFTAR PUSTAKA}

[1] Radian Khasani, Riqi. (2013). Evaluasi Kepuasan Pelanggan Terhadap Kinerja Management Proyek Kontraktor Besar Bangunan Gedung. Tesis Universitas Diponegoro. Semarang.

[2] Gibson,dkk. (1997). Organisasi, Perilaku, Struktur, Proses Jilid I. Jakarta: JakaBinarupa Aksara.

[3] Ervianto, W. (2005). Manajemen Proyek Konstruksi (Edisi Revisi). Yogyakarta: Andi

[4] Peraturan Presiden Republik Indonesia Nomor 54 Tahun 2010 Tentang Pengadaan Barang dan Jasa Pemerintah.

[5] Kariawan, Nyoman. (2011) Karakteristik Dan Kinerja Perusahaan Jasa Konstruksi Kualifikasi Kecil di Kabupaten Jembrana. Tesis Universitas Udayana. Denpasar.

[6] Widiyanto, Joko. (2010). SPSS for Windows Untuk Analisis Data Statistik dan Penelitian. Surakarta: BP-FKIP UMS.

[7] Martila, \& James. Importance Performance Analysis. Journal Of Service Science \& Management, Vol. 7.1977: 77-79

[8] Sekaran, U. (2006), Metodologi Penelitian untuk Bisnis, Edisi 4, Buku 1, Jakarta: Salemba Empat. 